\title{
PRIMARY HYPOTHYROIDISM QUALITY OF LIFE ASSESSMENT BY APPLICATION OF DIFFERENT QUESTIONNAIRES AND ITS DIFFERENT PROCESSING
}

\section{ISPITIVANJE KVALITETA ŽIVOTA OBOLELIH OD PRIMARNE HIPOTIREOZE PRIMENOM RAZLIČITIH UPITNIKA I METODA NJIHOVE OBRADE}

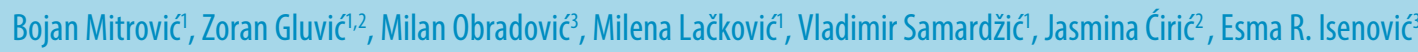

\section{Summary}

Primary hypothyroidism negatively affects patients' quality of life. Improving the quality of life is expected by establishing eutyreoid state using levothyroxine therapy. The quality of life can be "assessed" by applying various questionnaires, such as the general health questionnaire (GHQ12) and thyroid symptom questionnaire (TSQ).

The aims of present study were to: sum standard and modified-ranked answers of both questionnaires, rank the scores, test differences in the absolute values of the scores between the groups, classify obtained scores in different clusters (no distress, a minor, and major distress), and test differences in the distribution of frequencies of the respondents among them.

Cross-sectional study was conducted in Zemun Clinical Hospital and it included 90 subjects. The subjects were divided into three equal groups (30 subjects per group): hypothyroid without treatment, euthyroid with levothyroxine, and control, euthyroid group without treatment. The subjects answered the questions in the questionnaire, and the answers were then transformed into the ranking of two models- standard and modified, and then summarized. Statistical analysis was performed using the SPSS for Windows 18.0.

The average level of thyroid stimulating hormone (TSH) in the study population was $1.3 \pm 0.3(1.1-2.2) \mathrm{mU} / \mathrm{L}$. Average TSQm, TSQs, GHQm and GHQs scores were $14 \pm 7,13 \pm 6,11 \pm 7$ and $11 \pm 6$ and differed between groups. The lowest scores were registered in the group of levothyroxine-treated, regardless of the ranking models, with the level of TSH that indicates an adequate substitution levothyroxine. Average TSQs/TSQm and GHQs/GHQm scores show a statistical correlation with each other.

Scores and scores-defined clusters of both questionnaires are appropriate for clinical presentation shown by specific groups of the population. Considering that the average scores of the questionnaire differ from each other, and that both models rank-transformation of the same questionnaire give a similar score, it is sufficient to use one questionnaire from both categories of instruments for testing the quality of life. The ease of applying these questionnaires, independent of the transformation obtained in response ranges and their application when starting levothyroxine substitution, were used to assess the effectiveness of the therapy.

Keywords: hypothyroidism, levothyroxine, quality of life

\section{Sažetak}

Primarni hipotireoidizam negativno utiče na kvalitet života obolelih. Poboljšanje kvaliteta života očekuje se uspostavljanjem eutireoidnog stanja primenom levotiroksina. Kvalitet života se može "proceniti" primenom različitih upitnika, poput upitnika opšteg zdravlja (GHQ12; engl. General Health Questionnaire) i tireoidno specifičnog upitnika (TSQ; engl. Thyroid Symptom Questionnaire).

Ciljevi ovog rada su: sumiranje standardno i modifikovano rangiranih odgovora oba upitnika u skorove; ispitivanje postojanja razlika u apsolutnim vrednostima skorova među grupama ispitanika; svrstavanje dobijenih skorova u različite klastere (bez poremećaja, manji poremećaj, veliki poremećaj), i ispitivanje postojanja razlika u distribuciji frekvencija ispitanika među njima.

Studija preseka je sprovedena u KBC Zemun i obuhvatila je 90 ispitanica, koje su bile podeljene u tri jednake grupe (30 po grupi): hipotireoidnu bez terapije, eutiroidnu sa levotiroksinom i kontrolnu, eutireoidnu grupu bez terapije. Ispitanice su zaokruživale svoj odgovor na postavljena pitanja upitnika, koji je potom rangovno transformisan pomoću dva modela- standardnog i modifikovanog, a potom zbirno sumiran. Za statističku analizu korišcen je softver SPSS for Windows 18.0.

Prosečan nivo tireostimulišućeg hormona (TSH) u ispitivanoj populaciji je iznosio 1,3 $\pm 0,3$ (1,1-2,2) mU/L. Prosečni TSQm, TSQs, GHQm and GHQs skorovi su bili 14 $\pm 7,13 \pm 6,11 \pm 7, \mathrm{i} 11 \pm 6$ i razlikovali su se među grupama. Najniži skorovi su registrovani u grupi levotiroksinom-tretiranih, nezavisno od modela rangiranja, pri čemu je nivo TSH ukazivao na adekvatnu supstituciju levotiroksinom. Prosečni TSQs/TSQm i GHQs/GHQm skorovi pokazuju međusobnu statističku korelaciju.

Skorovi i skorom-definisani klasteri oba primenjena upitnika odgovaraju kliničkoj prezentaciji prikazanoj kroz grupe ispitivane populacije. S obzirom da se prosečni skorovi upitnika međusobno razlikuju, a da oba modela rangovne transformacije istog upitnika daju sličan skor, zaključujemo da je dovoljno koristiti po jedan upitnik iz obe kategorije instrumenata za ispitivanje kvaliteta života. Jednostavnost primene ovih upitnika, nezavisno od modela transformacije dobijenih odgovora u rangove, omogućava njihovu primenu pri započinjanju supstitucije levotiroksinom, ali takođe i proceni efikasnosti primenjene terapije.

Ključne reči: hipotireoidizam, levotiroksin, kvalitet života 
ocenjivanje simptoma i znakova hipotireoidizma koristi tireoidno specifični upitnik (TSQ; engl. Thyroid Symp-

Hipotireoidizam je klinički sindrom koji se karakteriše usporenjem metaboličkih procesa, a uzrokovan je nedostatkom ili neadekvatnim dejstvom tireoidnih hormona i može se javiti u bilo kom životnom dobu (1). Na osnovu nivoa na kome se nalazi uzrok, hipotireoidizam može biti: primarni (tireoidni uzrok), sekundarni (hipofizni uzrok - deficit tireostimulišućeg hormona (TSH)), tercijarni (hipotalamusni uzrok - deficit TSH oslobađajućeg hormona -TRH) i kvaternerni (periferna rezistencija na aktivnost tireoidnih hormona) $(1,2)$.

Najčešći uzrok hipotireoidizma odraslih je hronični autoimunski Hashimoto tireoiditis (strumogeni i atrofični), u kome je štitasta žlezda oštećena imunološkim procesima, što pokazuju markeri humoralne imunostiantitireoperoksidazna (ATPO At) i antitireoglobulinska antitela (ATg At). Smanjeno oslobađanje tireoidnih hormona vodi usporenju metaboličkih procesa u tkivima, smanjenju kalorigeneze, nakupljanja hidrofilnih mukopolisaharida (prevashodno hijaluronske kiseline), kao i retencije hidrofilnog jona natrijuma. Svi ovi procesi su uočljivi u intersticijskim prostorima kože i mišića, dajući kliničku sliku miksedema $(3,4)$.

Osnovni test za detekciju tireoidne disfunkcije je određivanje nivoa TSH i slobodne frakcije tiroksina (fT4) u krvi. Snižen nivo perifernih tireoidnih hormona (T4, fT4, fT3), uz povišen nivo TSH potvrđuje dijagnozu primarne hipotireoze, a zatim se evaluira etiologija bolesti. Na Hashimotov tireoiditis ukazuje pozitivan nalaz ATPO At i/ili ATg At. Ukoliko su nivoi fT4 u referentnom opsegu, a nivo TSH povišen, dijagnostikuje se supklinička (latentna) hipotireoza, koja je često samo laboratorijska dijagnoza (4, 6-8).

Lečenje hipotireoze se sastoji u oralnoj primeni supstitucione terapije čistim hormonom-levotiroksinom, a doziranje levotiroksina je zavisno od telesne mase i dnevna doza iznosi $0,5-2,0 \mu \mathrm{g} / \mathrm{kg}$, dok se kvalitet supstitucije prati određivanjem nivoa TSH u krvi $(5-7,9,10)$.

Kvalitet života (QoL; engl. Quality of Life) se po Svetskoj zdravstvenoj organizaciji definiše kao samosvojstvena percepcija osobe o životu u kontekstu sistema vrednosti prihvaćenog od društva u kom živi, a u odnosu na njihove ciljeve, očekivanja, standarde i brige (11). Instrumenti kojima se meri QoL mogu biti opšti, bolest specifični i upitnici kojima se mere simptomi i znaci bolesti. Opšti ili generički instrumenti su namenjeni ocenjivanju brojnih aspekata zdravlja, te su stoga korisni za primenu u različitim grupama bolesnika, opštoj, ali takođe i na zdravoj populaciji. Bolest-specifični upitnici ukazuju na individualno opažanje ispitanika o specifičnoj bolesti ili zdravstvenom problemu. Za ispitivanje opštih testova koristi se upitnik opšteg zdravlja (GHQ12; engl. General Health Questionnaire), dok se za ispitivanje tj.

tom Questionnaire) (11-13).

U ovom radu su ocenjivani kvalitet supstitucije levotiroksinom obolelih od hipotireoidizma merenjem nivoa TSH, kao i primenom upitnika, kao pomoćne i jednostavne metode, kojom se ispituje zadovoljstvo lečenjem. Ciljevi ovog rada su bili da se: izmeri kvalitet života $u$ ispitivanoj populaciji obolelih od hipotireoidizma upotrebom GHQ12 i TSQ upitnika: svrstaju skorovi dobijeni analizom upitnika po definisanim grupama (bez poremećaja, manji poremećaj i značajan poremećaj) kao i da se ispita da li postoji razlika u GHQ12 i TSQ skorovima među različitim grupama ispitanica (klinički hipotireoidni, eutireoidni na terapiji levotiroksinom, zdravi).

\section{MATERIJAL I METODE}

Studija preseka je sprovedena tokom 2013. godine u Službi za endokrinologiju, dijabetes i poremećaje metabolizma Kliničko-bolničkog centra (KBC) Zemun. Istraživanje je obuhvatalo 90 ispitanica, koje su dale pisanu saglasnost za učešće u studiji. Osnovni kriterijum za uključenje ispitanica u studiju bio je određen nivo TSH nezavisno od toga da li je ispitanica lečena ili ne od tireoidne bolesti, dok su za kontrolnu grupu regrutovane ispitanice koji su radile rutinski skrining za otkrivanje tireoidne bolesti, a koji su laboratorijske analize, uključujući i određivanje nivoa TSH obavile u referentnoj laboratoriji (Laboratorijska služba KBC Zemun).

Nivoi TSH su se određivali komercijalnim testovima na automatskom analizatoru Access-2 "Beckaman Coulter", a referentne vrednosti su bile 0,3-3,4 $\mathrm{mU} / \mathrm{ml}$. Ispitanice $(n=90)$ su podeljene $u$ tri jednake grupe, (30 u svakoj grupi). Kriterijum za formiranje grupa bile su vrednosti nivoa TSH. Prvoj grupi su pripale ispitanice, kod kojih je nivo TSH $>10 \mathrm{mU} / \mathrm{ml}$ (inicijalni klinički hipotireoidizam), a koje su bez supstitucione terapije levotiroksinom. Druga grupa je obuhvatala ispitanice kod kojih je nivo TSH u eutireoidnom rangu, a koje su već na supstitucionoj terapiji nezavisno od etiologije tireoidne bolesti. Treća (kontrolna) grupa je obuhvatala zdrave, laboratorijski eutireoidne ispitanice, koji nisu dobijale supstituciju levotiroksinom. Svim ispitanicima su potom dati na popunjavanje GHQ12 i TSQ upitnici, koji su nakon popunjavanja, vraćeni istraživaču. Istraživač je obavio skorovanje dobijenih odgovora po standardnom (Likertovom) i modifikovanom modelu, a nakon toga grupisao ispitanice $\mathrm{u}$ odgovarajuće skor-klastere. Struktura odgovora je identična u oba upitnika, pri čemu se zaokruživao jedan od četiri ponuđena odgovora. U obradi zaokruženih odgovora, odgovori su transformisani u rangove - numeričke vrednosti sa rastućom tendencijom, od najpovoljnijeg ka najnepovoljnijem ishodu. Standardni (Likertov) skor ima vrednosti 0, 1, 2 i 3 (12), a maksimalna vrednost zbira iz- 
nosila je 36. Veći skor ukazuje na veći stepen izraženosti simptoma hipotireoidizma i narušenosti opšteg zdravstvenog stanja, tj. kod lečenih na nedovoljnu susptitucionu terapiju. U modifikovanom skoru odgovori pod d su se vrednovali sa 4 boda (numerički rangovi odgovora su $0,1,2$ i 4), što povećava maksimalni zbir skorovanja na 48 (13). Grupisanje kalkulisanih skorova za oba upitnika urađeno je na isti način po sledećem principu: ukoliko je skor imao vrednost 0-15 okarekterisan je kao bez poremećaja, 16-25 je umeren poremećaj, dok ukoliko je vrednost bila $\geq 25$ to je bio ozbiljan poremećaj.

\section{STATISTIČKA ANALIZA}

U statističkoj obradi podataka korišćene su metode deskriptivne i analitičke statistike. Korišćene su mere centralne tendencije (aritmetička sredina i medijana), kao i mere varijabiliteta (standardna devijacija i koeficijent varijacije). Za procenu značajnosti razlike i povezanosti korišćeni su Spearmanov test korelacije ranga, dok su se za procenu značajnosti razlike između dve grupe ispitanika korišćeni $\chi^{2}$ test u slučajevima kategorijskih podataka, odnosno Mann-Whitney test u slučajevima intervalnih podataka, koji ne slede normalnu distribuciju. U slučajevima gde je ispitivana značajnost razlike između tri grupe ispitanika, koristila se jednofaktorska neparametarska analiza varijanse (Kruskal-Wallis). Nivo statističke značajnosti bio je 0,05. Za statisticku obradu dobijenih rezultata korišćen je statistički paket SPSS for Windows 18.0.

\section{ReZultati}

Prosečna životna dob ispitanica iznosila je oko 45 (19 - 88) godina. Uočena je značajna razlika u prosečnoj starosti među posmatranim grupama - zdrava kontrola, eutireoidni na terapiji levotiroksinom i hipotireoidni, (Tabela 1) $\left(\chi^{2}=6,301, p<0,01\right)$. Prosečan nivo TSH za celu ispitivanu populaciju iznosio je $1,3(1,0-35,5) \mathrm{mIU} /$ $\mathrm{ml}$ i razlikovao se značajno među pomenutim grupama $\left(\chi^{2}=62,069, p<0,01\right)$. Takođe je rezultati pokazuju da su godine života statistički značajno uticale na nivo TSH $(\rho=0,338, p<0,01)$. Prosečni TSQ skorovi su za standardni TSQ skor (TSQs) iznosili 14 \pm 7 (Med 12, interval varijacije 1-38), dok su za modifikovani TSQ skor (TSQm) iznosili $13 \pm 6$ (Med 12, interval varijacije 1-31) (Tabela 2). Prosečni GHQ skorovi za standardni GHQ12 (GHQs) i modifi-

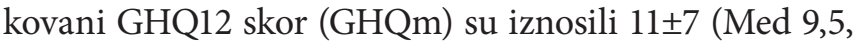
interval varijacije 1-40) i $11 \pm 6$ (Med 9.5, interval varijacije 1-32) (Tabela 2). U Tabeli 3 prikazane su međugrupne razlike u pogledu pomenutih skorova. Uočeno je da su se skorovi statistički značajno razlikovali među grupama ispitanika $\left(\chi_{\mathrm{TSOs}}^{2}=56.026 ; \chi_{\mathrm{TSQm}}^{2}=55,998 ; \chi_{\mathrm{GHQS}}^{2}=47,780\right.$; $\left.\chi_{\mathrm{GHQm}}^{2}=47,769 ; \mathrm{df}=2 ; \mathrm{p}<0,01\right)$.

Prosečne vrednosti TSQs i TSQm, kao i GHQs i GHQm su međusobno korelisale $u$ ispitivanoj populaciji $\left(\rho_{\text {TSQ }}\right.$ $\mathrm{GHQ}=0.99 ; \mathrm{p}<0.01)$. Uočena je statistički značajna razlika uporednom analizom distribucije frekvencija ispitanika po grupama $\left(\chi_{\mathrm{TSQ} / \mathrm{GHQ}}^{2}=39.627, \chi_{\mathrm{TSQm} / \mathrm{GHQs}}^{2}=37.968\right.$, $\left.\chi_{\mathrm{TSQ} / \mathrm{GHQm}}^{2}=39.627, \chi_{\mathrm{TSQm} / \mathrm{GHQm}}^{2}=37.968 ; \mathrm{df}=4 ; \mathrm{p}<0.01\right) . \mathrm{Na}$ grafikonu 1 (a-d) prikazana je distribucije frekvencija ispitanika grupisanih po skorovima.

\section{Diskusija}

Istraživanja čiji su rezultati prikazani u ovom radu, sprovedena su po tipu studije preseka, koja je obuhvatila 90 ispitanica, sa ciljem da se ispita kvalitet supstitucije levotiroksinom obolelih od hipotireoze, upotrebom TSQ i GHQ strukturisanih upitnika, kao i da se ispita uticaj različitih modela obrade dobijenih odgovora u upitnicima (standardni i modifikovani) na ukupan TSQ/GHQ skor i tako proceni kvalitet života ispitanica. Dobijeni rezultati pokazuju: da je kvalitet supstitucije levotiroksinom adekvatan u tretiranoj hipotireoidnoj grupi; da se apsolutni i grupno kategorisani TSQ i GHQ skorovi razlikuju u ispitivanoj populaciji, kao i da je uticaj modifikovanog modela rangiranja strukturisanog odgovora iz upitnika uočen samo u grupi jasno ispoljenog hipotireoidizma bez supstitucije levotiroksinom, i to TSQm $>$ TSQs, tj.

Tabela 1. Prikaz praćenih parametara po grupama ispitanika

\begin{tabular}{|c|c|c|c|}
\hline Parametar & Levotiroksin eutireoidna gr. & $\begin{array}{l}\text { Ispoljen hipotireoidizam, } \\
\text { bez levotiroksinske supst. }\end{array}$ & $\begin{array}{l}\text { Zdrava eutireoidna gr., } \\
\text { bez supstitucije levotiroksinom }\end{array}$ \\
\hline $\begin{array}{l}\text { Godine života } \\
{[\mathrm{X} \pm \mathrm{SD}(\min -\mathrm{max})]}\end{array}$ & $41 \pm 12(21-63)$ & $51 \pm 15(27-88)$ & $44 \pm 18(19-81)$ \\
\hline $\begin{array}{l}\text { TSH }(\mathrm{mIU} / \mathrm{ml}) \\
{[\operatorname{Med}(\min -\max )]}\end{array}$ & $1,3 \pm 0,3(1,1-2,2)$ & $14,5 \pm 5,3(9,5-35,5)$ & $1,2 \pm 0,1(1,0-1,4)$ \\
\hline $\begin{array}{l}\text { TSQs } \\
{[\text { Med (min-max)] }}\end{array}$ & $8(1-15)$ & $18(10-31)$ & $12(6-15)$ \\
\hline $\begin{array}{l}\text { TSQm } \\
{[\operatorname{Med}(\min -\max )]}\end{array}$ & $8(1-15)$ & $19(10-38)$ & $12(6-15)$ \\
\hline $\begin{array}{l}\text { GHQs } \\
{[\operatorname{Med}(\min -\max )]}\end{array}$ & $7(1-31)$ & $17(8-40)$ & $8(3-13)$ \\
\hline $\begin{array}{l}\text { GHQm } \\
{[\operatorname{Med}(\min -\max )]}\end{array}$ & $7(1-38)$ & $16(8-32)$ & $8(3-13)$ \\
\hline
\end{tabular}

TSQs - standardni TSQ skor; TSQm - modifikovani TSQ skor; GHQs - standardni GHQ skor; GHQm - modifikovani GHQ skor 
Tabela 2. Prikaz distribucije frekvencija ispitanika po grupisanim skorovima

$\begin{array}{llll}\text { Parametar } & \begin{array}{l}\text { Levotiroksin eutireoidna } \\ \text { grupa }\end{array} & \begin{array}{l}\text { Jasan hipotireoidizam, bez levoti- } \\ \text { roksinske supstitucija }\end{array} & \begin{array}{l}\text { Kontrolna } \\ \text { bez levotiroksinske supstitucija }\end{array} \\ \begin{array}{l}\text { TSQs } \\ \text { 1. Bez poremećaja }\end{array} & 1.30(100 \%) & 1.4(13,3 \%) & 1.30(100 \%) \\ \text { 2. Umeren poremećaj } & 2.0 & 2.21(70 \%) & 2.0 \\ \text { 3. Ozbiljan poremećaj } & 3.0 & 3.5(16,7 \%) & 3.0 \\ \text { TSQm } & & & 1.30(100 \%) \\ \text { 1. Bez poremećaja } & 1.30(100 \%) & 1.4(13,3 \%) & 2.0 \\ \text { 2. Umeren poremećaj } & 2.0 & 2.18(60 \%) & 3.0 \\ \text { 3. Ozbiljan poremećaj } & 3.0 & 3.8(26,7 \%) & 1.30(100 \%) \\ \text { GHQs } & & & 2.0 \\ \text { 1. Bez poremećaja } & 1.29(96,7 \%) & 1.12(40 \%) & 3.0 \\ \text { 2. Umeren poremećaj } & 2.0 & 2.16(53,3 \%) & 1.30(100 \%) \\ \text { 3. Ozbiljan poremećaj } & 3.1(3,3 \%) & 3.2(6,7 \%) & 2.0 \\ \text { GHQm } & & 1.12(40 \%) & 3.0 \\ \text { 1. Bez poremećaja } & 1.29(96,7 \%) & 2.16(53,3 \%) & \\ \text { 2. Umeren poremećaj } & 2.0 & 3.2(6,7 \%) & \\ \text { 3. Ozbiljan poremećaj } & 3.1(3,3 \%) & & \end{array}$

TSQs - standardni TSQ skor; TSQm - modifikovani TSQ skor; GHQs - standardni GHQ skor; GHQm - modifikovani GHQ skor

Tabela 3. Intergrupne razlike u skorovima

\begin{tabular}{|c|c|c|c|}
\hline Skor & $\begin{array}{l}\text { Eutireoidne pod levotiroik- } \\
\text { sinom } \\
\text { vs } \\
\text { Klinički hipotireoidizam }\end{array}$ & $\begin{array}{l}\text { Eutireoidne pod levotiroik- } \\
\text { sinom } \\
v s \\
\text { Zdravi }\end{array}$ & $\begin{array}{c}\text { Klinički hipotireoidizam } \\
v s \\
\text { Zdravi }\end{array}$ \\
\hline TSQs & $21,000^{\mathrm{xx}}$ & $246,000^{\mathrm{xx}}$ & $42,000^{\mathrm{xx}}$ \\
\hline TSQm & $21,000^{\mathrm{xx}}$ & $244,000^{\mathrm{xx}}$ & $43,000^{\mathrm{xx}}$ \\
\hline GHQs & $54,500^{x}$ & $318,500^{x x}$ & $54,500^{\mathrm{xx}}$ \\
\hline GHQm & $54,500^{x}$ & $318,500^{\mathrm{xx}}$ & $54,500^{\mathrm{xx}}$ \\
\hline
\end{tabular}

${ }^{\mathrm{x}} \mathrm{p}<0.05,{ }^{\mathrm{xx}} \mathrm{p}<0.01$

TSQs - standardni TSQ skor; TSQm - modifikovani TSQ skor; GHQs - standardni GHQ skor; GHQm - modifikovani GHQ skor

A.

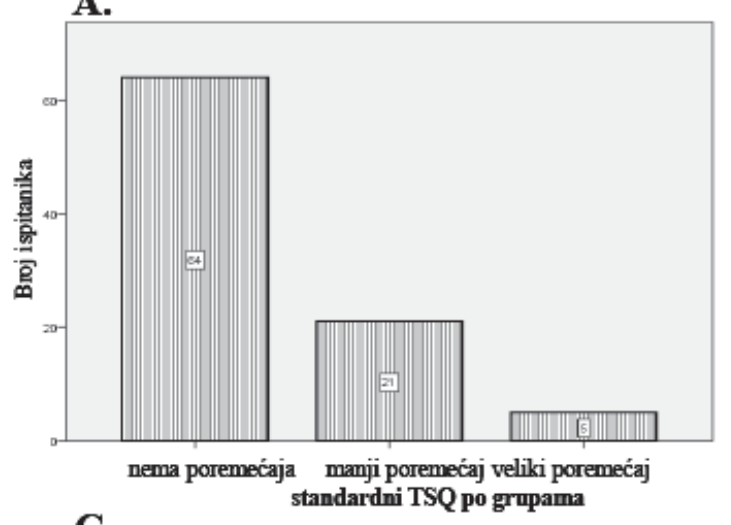

C.

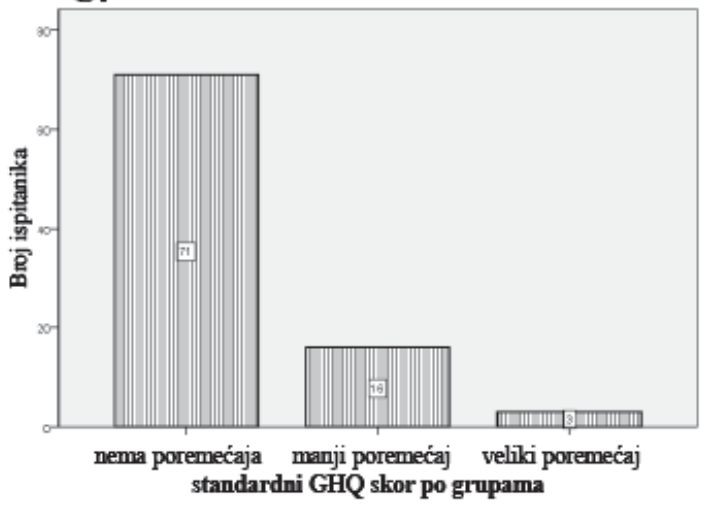

B.

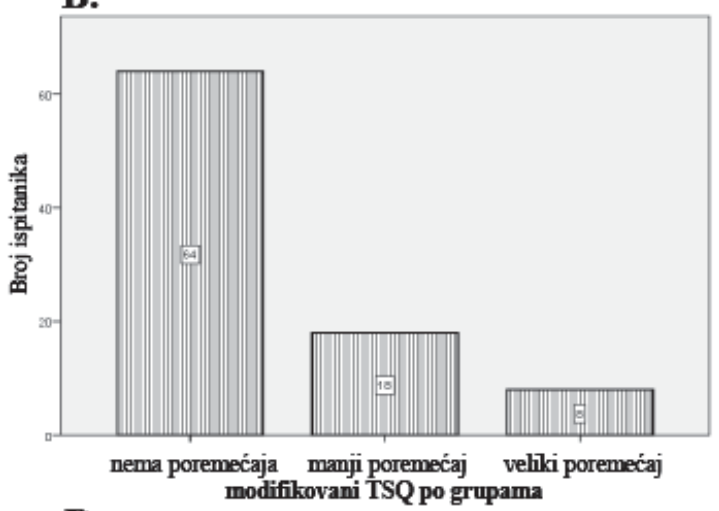

D.

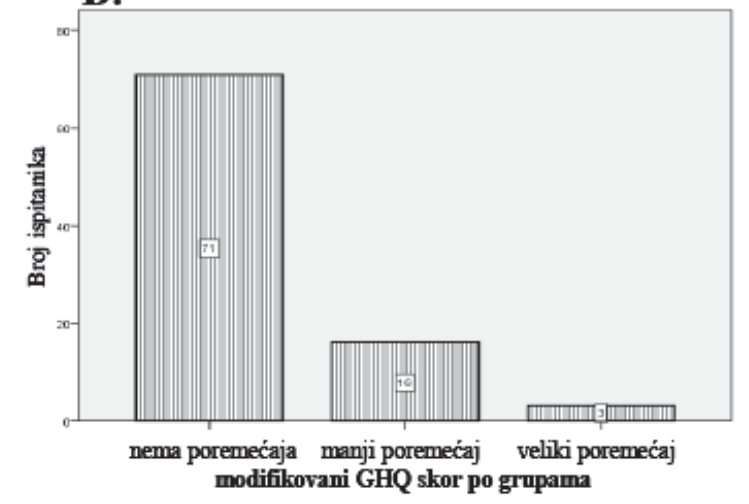

Grafik 1. Distribicija frekvencija ispitanika po kategorijama za: (A) TSQs, (B) TSQm (C) GHQsi (D) GHQm 
GHQs>GHQm, što ukazuje na veći uticaj modifikacije u „bolest-specifičnim“, nego „opštim“ upitnicima za ispitivanje kvaliteta života. Imajući u vidu mali broj ispitanica, ovaj zaključak ne treba generalizovati.

Etiologija hipotireoze među ispitivanim ispitanicama je bila autoimuna. I pored postojanja heterogenosti ispitivane populacije u pogledu godina života, uočena je očekivana pozitivna korelacija između nivoa TSH i godine zivota, što je u skladu sa smanjenim funkcionalnim kapacitetom štitaste žlezde, uzrokovanog delom životnom dobi, ali i progresijom autoimunskog procesa (15).

Prosečni apsolutni TSQ i GHQ skorovi su se razlikovali u ispitivanoj populaciji. Medijana svih apsolutnih skorova $\mathrm{u}$ ispitivanoj populaciji bila je $<15$, čime su ispitanici pripadali grupi bez poremećaja za oba upitnika. Nakon upoređivanja različitih modela rangiranja istog upitnika uočeno je da oni međusobno pozitivno korelišu, što dovodi u pitanje postojanje različitih modela skorovanja. Ukoliko se zna da je smisao modifikovanog rangiranja skora u pojačavanju kontrasta davanjem većeg broja bodova najnepoželjnijem odgovoru, onda se nameće zaključak da ono može biti od pomoći kliničaru za uveđenje supstitucije levotiroksinom. Takođe, ukoliko je obolela osoba na terapiji, kliničar može prilagoditi dozu levotiroksina, ukoliko je skor kvaliteta života nepovoljan $(14,15)$. Postojanje podatka o kvalitetu života bi trebalo da bude samo jedan od pomoćnih parametara, koji bi uticali na odluku kliničara, a nikako jedinstven. Od ostalih paramatera, od pomoći mogu biti godine života, trudnoća, laktacija, dislipidemija, ispoljenost ateroskleroze, endotelna disfunkcija i brojni drugi $(15,16)$.

Analizom podataka po pojedinačnim grupama ispitanika, uočava se da su i standardni i modifikovani TSQ i GHQ skorovi $>15$ jedino u grupi hipotireoidnih ispitanika bez supstitucije levotiroksinom i tako ih svrstavaju u grupu umerenih poremećaja. Pored toga, vrednosti TSQ skorova su veće od vrednosti GHQ skorova u istoj grupi. Iamjući u vidu da je naša studija, studija preseka, ne može se znati koliko zaista bolest traje. Međutim, kod osoba koje su hipotireoidne, prve izmene u kvalitetu života se mogu otkriti u domenu simptoma kojima se meri izraženost hipotireoidizma, a potom tireoidna bolest utiče i na opšte aspekte kvaliteta života (17).

U subpopulaciji eutireoidnih ispitanika, vrednosti TSQ i GHQ skorova su niže u grupi eutireoidnih ispitanika pod supstitucijom, nego kod kontrolne eutireoidne grupe. To svakako potvrđuje izuzetan efekat levotiroksina na oba aspekta kvaliteta života hipotireoidnih bolesnika. U našoj studiji, taj efekat je naglašeniji za sferu ispoljenosti tireoidnih simptoma, što se može objasniti postojanjem hipotireoidne bolesti u inicijalnoj fazi, ili je možda razlog rani odgovor na supstituciju levotiroksinom, dok se efekat na opšti kvalitet života može očekivati u dužoj primeni leka ili efekat nastupa kasni- je. Interesantni su rezultati koji pokazuju da su nivoi TSH niži u kontrolnoj grupi ispitanika bez supstitucije levotiroksinom u odnosu na eutireoidne, levotiroksinom supstituisane. Prosečna vredost TSH u ovoj grupi je bila nešto veća od $1 \mathrm{mU} / \mathrm{ml}$, koje brojni autori smatraju karakteristikom kvalitetne supstitucije $(13,17)$. Pojedini kliničari su, u cilju poboljšanja kvaliteta života laboratorijski eutireoidnih osoba, koji su se osećali hipotireoidno, dodavali u terapiju T3 (18), ili dodavali levotiroksin do nivoa subnormalnog opsega TSH (19), što je dovelo do stvaranja nepotrebnog rizika od atrijalne fibrilacije ili pogoršanja osteoporoze, kao neželjenih efekata supstitucije levotiroksinom (20-22). Međutim, u novije vreme sve više je prisutno mišljenje da se prag za TSH još vise spusti, posebno kod mladih osoba, potencijalnih trudnica, čime bi se hiper/eutireoidno granica još više približila, što vodi ka stavu da je bolje i tretirati osobu, nego je „ostaviti“ hipotireoidnom. Šta će određivati kategoriju hipotireoidnih, zavisi i od drugih faktora, pomoćnih parametra i instrumenta, a među njima su i upitnici za procenu kvaliteta života. Kao i u svim drugim bolestima i stanjima, individualizacija tretmana hipotireoidno obolelog je osnova racionalnog lečenja $(13,17,22,23)$. Na osnovu rezultata dobijenih u okviru naše studije, može se uočiti da su doze koje indukuju laboratorijski eutireoidizam, dovoljne za poboljšanje obe sfere kvaliteta života populacije hipotireoidnih. I pored značaja u doprinosu davanja većeg skora upotrebom modifikovanog rangiranja na račun odgovora $d$, nije zabeleženo značajno pomeranje broja ispitanika iz kategorije bez distresa u kategoriju malog/velikog distresa u svim grupama za oba skora.

Racionalna farmakoterapija zahteva da se oboleli tretiraju, ali i da tretirani imaju adekvatan odgovor u smislu boljitka. Postizanje preporučenog nivoa TSH u serumu primenom levotiroksina ne korelira uvek sa poboljšanjem kvaliteta života prema dobijenim skorovima upitnika. Ukoliko se ispitanici ne osećaju bolje, oni mogu smatrati da je terapija neuspešna kao i da ne sarađuju u lečenju, što dodatno produbljuje hipotireozu, koja pored bolesti per se, ima sada i reperkusije na ostale sisteme, prevashodno zbog akceleracije ateroskleroze i sledstvenog makroangiopatskog ozbiljnog komorbiditeta, kao i učinka na neurokogniciju $(18,22,24)$. Upravo zbog toga je važno primeniti upitnik, kako bi se otkrili ispitanici koji imaju umerene ili ozbiljne poremećaje kao i da se isti dalje prate retestiranjem, čime se obezbeđuje individualni pristup pacijentu, otkivaju se uzroci lošeg kvaliteta života i poboljšava komplijansa u lečenju. Poseban značaj upitnika može biti i u njihovoj primeni kod osoba sa supkliničkim hipotireoidizmom. Povećani skorovi na primenjenim testovima mogu biti dodatni, pomoćni razlog za započinjanje supstitucije levotiroksinom. Pored toga, registrovanjem umerenog poremećaja kategorije u upitnicima, mogu biti od pomoći za odabir onih latentno hipotireoidnih, koji ćese češće pratiti. Kod tretiranih bolesnika, sprovođenje ovih upitnika može ukazati kliničaru na neadekvatnu dozu levotiroksina ili lošu komplijansu obolelog $(20,22)$. 
Modifikacijom standardnog modela rangiranja dobijenih odgovora dobije se veći ukupni skor i naglašavaju nepoželjni i potencijalno „najhipotireoidniji“ odgovori. $\mathrm{Na}$ taj način bi kliničar mogao da se „ubedi“ da ranije započne supstituciju levotiroksinom svom pacijentu. Obično sam skor upitnika nije od dovoljne pomoći, ali ako je u sadejstvu sa drugim pomoćnim faktorima, može dati doprinos u tom pravcu $(13,14)$.

\section{ZAKLJUČAK}

U ovoj studiji skorovi istog upitnika sa različitim načinom rangovne transformacije dobijenog odgovora su se uporedno razlikovali samo u grupi jasnog hipotireoidizma bez levotiroksinske terapije. Obzirom da nije bilo značajnog učinka modifikacije u eutireoidnim grupa- ma, koje su po veličini male, može se reći da je on stoga i očekivan, a rezultati delimično limitirani veličinom ispitivane populacije. Pokazan je povoljan uticaj terapije levotiroksinom na kvalitet života obolelih od hipotireoze, upotrebom opštih i bolest-specifičnih upitnika. Laki za izvođenje, razumljivi i jednostavni TSQ i GHQ upitnici se mogu preporučiti prevashodno kao pomoćni parametri za uvođenje supstiticije u hipotireoidnim stanjima, ali i u kontroli komplijanse i kvaliteta supstitucije tretiranih ispitanika.

\section{ZAHVALNICA}

Ovaj rad je jednim delom podržan projektom broj 173033 (E.R.I.) finansiranim od strane Ministarstva prosvete, nauke i tehnološkog razvoja.

\section{Literatura}

1. Trbojević B. Tiroidna žlezda: patofiziološke osnove i klinički pristup. Beograd:ČIP Štampa; 1994

2. Slijepčević D, Vujović S, Nestorović Z. Humana klinička endokrinologija. Beograd:Obeležja; 2002.p. 164-76.

3. Greenspan FS. The Thyroid Gland. In: Greenspan FS, Gardner DG eds. Basic and Clinical Endocrinology. $7^{\text {th }}$ ed. London: Lange Medical Books; 2004.p. 215-94.

4. Trbojević B, Marina Đ. Dijagnoza hipotireoze. In: Micić D, Popović-Brkić V, eds. Acta Clinica-Hipotireoza. $1^{\text {st }}$ ed. Beograd: Klinički Centar Srbije; 2008.p. 39-53.

5. Petakov M, Beleslin B, Ćirić S. Oboljenja štitaste žlezde. In: Micić D, Damjanović S, eds. Acta Clinica-funkcionalna ispitivanja u endokrinologiji. $1^{\text {st }}$ ed. Beograd: Klinički Centar Srbije; 2004.p. 32-44.

6. DeMoura Souza A, Sichieri R, Association between serum TSH concentration within normal range and adiposity. EJE 2011;165: 11-5.

7. Biondi B. Mechanismus in endocrinology: Heart failure and thyroid dysfunction. EJE 2012;167:609-18.

8. Moeller LC, Fuerer D. Thyyroid hormone, thyroid hormon receptous, and cancer:a clinical perspective. Endocr Relat Cancer 2013;20:R19-29.

9. Ross DS. Serum TSH measurement for assessment of thyroid function and disease. Endocrinol Metabol Clin North Am 2001;30:245-64.

10. Roberts CG, Landenson DW. Hypothyroidism. Lancet 2004;363:793-803.

11. Razvi S, McMillan CV, Weaver JU. Instruments used in measuring symptoms, health status and quality of life in hypothyroidism: a systematic qualitative review. Clinical Endocrinology 2005; 63: 617-24.

12. Goldberg DP, Hiller VF. A scaled version of the General Health Questionnaire. Psychological Medicine 1979;9:139-45.

13. Saravanan P, Chau W-F, Roberts N, Vedhara K, Greenwood R, Dayan CM. Psychological well-being in patients on "adequate" doses of L-thyroxine: results of a large, controlled community-based questionnaire study. Clinical Endocrinology 2002;57:577-85.

14. Walsh JP. Dissatisfaction with thyroxine therapy- colud the patients be right? Current Opinion in Pharmacology 2002;2:717-22.

15. Razvi S, McMillan CV, Weaver JU. Instruments used in measuring symptoms, health status and quality of life in hypothyroidism: a systematic qualitative review. Clinical Endocrinology 2005;63:617-24.

16. Wekking EM, Appelhof BC, Fliers E, Schene AH, Huyser J, Tijssen JGP et al. Cognitive functioning and well-being in euthyroid patients on thyroxine replacement therapy for primary hypothyroidism. EJE 2005;153:747-53.

17. Samuels MH, Schuff KG, Carlson NE, Carello P, Janowski JS. Health status, mood, and cognition in experimentally induced subclinical hypothyroidismus. JCEM 2007;92:2545-51.

18. Bunevicius R, Kazanavicius G, Zalikevicius R, Prange AJ. Effects of thyroxine as compared with thyroxine plus triiodothyronine in patients with hypothyroidism. NEJM 1999;340:424-9.

19. Carr D, McLeod DT, Parry G, Thornes HM. Fine adjustment of thyroxine replacement dosage: comparison of the thyrotrophin releasing hormone test using a sensitive thyrotrophin assay with measurement of free thyroid hormones and clinical assessment. Clin Endocrinol (Oxf) 1988; 28: 325-333.

20. Walsh JP, Shiels L, Mun Lim EE, Bhagat CI, Ward LC, Stuckey BGA et al. Combined thyroxine/liothyronine treatment does not improve well-being, quality of life, or cognitive function compared to thyroxine alone: a randomized controlled trial in patients with primary hypothyroidism. JCEM 2003; 88: 4543-50.

21. Walsh JP, Ward LC, Burke V, Bhagat CI, Shiles L, Henley D et al. Small changes in thyroxine dosage do not produce measurable changes in hypothyroid symptoms, well-being, or quality of life: results of double-blind, randomized clinical trial. JCEM 2006; 91: 2624-30.

22. Bianchi GP, Zaccheroni V, Solaroli E, Vescini F, Cerutti R, Zoli M et al. Health-related quality of life in patients with thyroid disorders. Qual of Life Res 2004; 13: 45-54.

23. Toft AD, Beckett GJ. Thyroid function tests and hypothyroidism. BMJ 2003; 326: 295-6.

24. Ladenson PW. Psychological well-being in patients. Clin Endocrinol (Oxf) 2002; 57: 577-85. 